\title{
SRGAP3 Gene
}

National Cancer Institute

\section{Source}

National Cancer Institute. SRGAP3 Gene. NCI Thesaurus. Code C97797.

This gene plays a role in GT Pase-mediated signaling. 